\title{
ZNRF3 wt Allele
}

National Cancer Institute

\section{Source}

National Cancer Institute. ZNRF3 wt Allele. NCI Thesaurus. Code C118320.

Human ZNRF3 wild-type allele is located in the vicinity of 22q12.1 and is approximately $174 \mathrm{~kb}$ in length. This allele, which encodes E3 ubiquitin-protein ligase ZNRF3 protein, plays a role in the both Wnt pathway modulation and protein modification. 